\title{
Behavioral patterns and movement intensity of Sotalia guianensis (P. ). van Bénéden) (Cetacea, Delphinidae) in two different areas on the Brazilian coast
}

\author{
Fábio G. Daura-Jorge 1; Marcos R. Rossi-Santos 2; Leonardo L. Wedekin ${ }^{1} \&$ Paulo C. Simões-Lopes ${ }^{1}$ \\ ${ }^{1}$ Departamento de Ecologia e Zoologia, Universidade Federal de Santa Catarina. Campus Universitário, 88040-970 \\ Florianópolis, Santa Catarina, Brasil. E-mail: daurajorge@yahoo.com.br \\ 2 Projeto Boto Sotalia do Sul da Bahia, Instituto Baleia Jubarte. Rua Barão do Rio Branco 26, 45900-000 Caravelas, Bahia, Brasil.
}

\begin{abstract}
The behavioral patterns of the estuarine dolphin, Sotalia guianensis (P. J. van Bénéden, 1864), were compared between two populations along the Brazilian coast: Caravelas (Bahia), along the eastern coast, and Norte Bay (Santa Catarina), along the southern coast. Applying the focal-group sampling in both areas, information such as the geographic position (UTM) of groups and predominant behavioral patterns were obtained. Geographic positions were used to calculate the total distance traveled by estuarine dolphin groups on each observation day. Since the distance traveled varies with time, the daily mean speed of the dolphin's group was used as an index of movement intensity. Two comparable and easily recognizable behavioral patterns were considered: travelling and foraging. Overall movement intensity and behavioral pattern frequency were similar between both areas. However, a seasonal variation was observed in both parameters in Norte Bay, while in Caravelas these parameters were homogeneous throughout the year.Variation in the behavior of the estuarine dolphin was consistent with variations in environmental factors, such as water temperature.

KEY WORDS. Behavior; estuarine dolphin; Caravelas estuary; Norte Bay; spatial requirements.
\end{abstract}

RESUMO. Padrões comportamentais e intensidade de movimentos de Sotalia guianensis ( $\mathrm{P}$. J. van Bénéden) (Cetacea, Delphinidae) em duas diferentes áreas da costa brasileira. Os padrões comportamentais do botocinza, Sotalia guianensis (P. J. van Bénéden, 1864), foram comparados entre duas populações da costa brasileira: Caravelas (Bahia), na costa leste, e Baía Norte (Santa Catarina), na costa sul. Utilizando o método de grupo-focal em ambas as áreas, informações como posições geográficas (UTM) do grupo e padrão comportamental predominante foram coletadas. A posição geográfica foi utilizada para o cálculo da distância total percorrida por um grupo de botos-cinza em cada área de observação. Como a distância é uma medida que varia com o tempo, a velocidade média diária do grupo de botos foi usada como um índice de intensidade de movimento. Dois padrões comportamentais comparáveis e facilmente reconhecíveis foram considerados: deslocamento e forrageamento. A intensidade de movimentos e a freqüência dos padrões comportamentais foram similares entre as duas áreas. No entanto, foi observada uma variação sazonal dos dois parâmetros para a Baía Norte, enquanto em Caravelas estes parâmetros foram homogêneos ao longo do ano. A variação no comportamento do boto-cinza acompanhou a variação de fatores ambientais como a temperatura.

PALAVRAS-CHAVE. Baía Norte; comportamento; estuário de Caravelas; fatores ambientais; requerimento espacial.

Variation of ecological factors may influence behavioral patterns of individuals, social groups or a population that inhabits an area (KreBs \& DAVIES 1993). This influence is largely documented for species of terrestrial mammals, such as primates, whose behavior may be influenced by availability of food resources in a variety of ways (OATES 1987). Food resources in the marine environment may present a complex pattern of distribution and abundance in space and time (e.g. LAevastu \& HaYes 1981), and we should expect that marine predators may also respond, behaving in different manners, according to availabil- ity of food resources. In fact, the behavior of small cetaceans has been linked to diverse environment cycles and variation (e.g. WÜrsig \& WÜrsig 1979, 1980, Wells et al. 1980, Shane et al. 1986, Bräger 1993, Ballance \& Pitman 1998). A great part of these environment cycles and variations are indirect factors that may influence prey abundance and/or distribution.

According to SHANe (1990b), behavioral flexibility of cetaceans can be studied from at least three viewpoints: (1) individuals from the same population with differences in behavior; (2) diverse behaviors with a common function; and (3) 
different behaviors for the same function developed by separated populations in distinct habitats. The present work approaches the last perspective comparing the behavior characteristics of two populations of the estuarine dolphins, Sotalia guianensis (P. J. van Bénéden, 1864), on the Brazilian coast: one off the eastern coast of Brazil, in a typical tropical environment; and the other off the southern coast of Brazil, in a subtropical environment, at the southern limit of distribution of this species (SIMÕES-LOPES 1988).

The estuarine dolphin has a wide distribution along the Brazilian coast, inhabiting mainly protected coastal waters such as bays and estuaries (Borobia et al. 1991). Studies on the behavior and ecology of $S$. guianensis along the Brazilian coast are fragmented and focused on single populations (e.g. Monteiro-Filho 1995, Geise et al. 1999, Flores 1999, Santos et al. 2000, Araújo et al. 2001, Cremer et al. 2004, Daura-Jorge et al. $2004,2005)$. Where the species is studied, the use of different methods in each area along its distribution, limits the potential for comparative approaches and its testability. Therefore, this species' responses to environment variation remain unknown.

The aim of the present work is to compare the behavior patterns and movement intensity of two Sotalia guianensis populations in different areas of the Brazilian coast, in order to test if the species has different behavior strategies to cope with different environmental conditions related to both the space and time axis.

\section{MATERIAL AND METHODS}

\section{Study areas}

Norte Bay is located between Santa Catarina Island and the mainland, southern Brazil $\left(27^{\circ} 30^{\prime} \mathrm{S}, 48^{\circ} 32^{\prime} \mathrm{W}\right)$. It is a coastal bay delimited by rocky shores, sandy beaches, and small patches of mangrove forests, which are probably responsible for increasing the marine productivity of the area. It presents a mean depth of $3.5 \mathrm{~m}$, rarely exceeding $10 \mathrm{~m}$ (in both south and north channels) and the temperature varies markedly throughout the seasons (Laboratório de Cultivo de Moluscos Marinhos, Universidade Federal de Santa Catarina - data gathered in 2000 and not published, Fig. 1). Caravelas Estuary $\left(17^{\circ} 00^{\prime} \mathrm{S}, 39^{\circ} 30^{\prime} \mathrm{W}\right)$, eastern Brazil, is located in the coastal waters of the Abrolhos Bank, an enlargement of the Brazilian continental shelf. This region is characterized by an open coast protected by banks of coral reefs and with a predominance of sandy beaches and large mangroves. Influenced exclusively by the Brazil Current, this coast is a typical tropical ecosystem with a high diversity of species (NONAKA et al. 2000) and low production (EKAU \& KNOPPERs 1999). The Caravelas Estuary system is the second largest mangrove forest of Brazil's northeast region, with an area of approximately $66 \mathrm{~km}^{2}$ (HeRz 1991). It presents a low temperature variation throughout the seasons (Instituto Baleia Jubarte - data gathered since 2002 and not published, Fig. 1).

Revista Brasileira de Zoologia 24 (2): 265-270, junho 2007

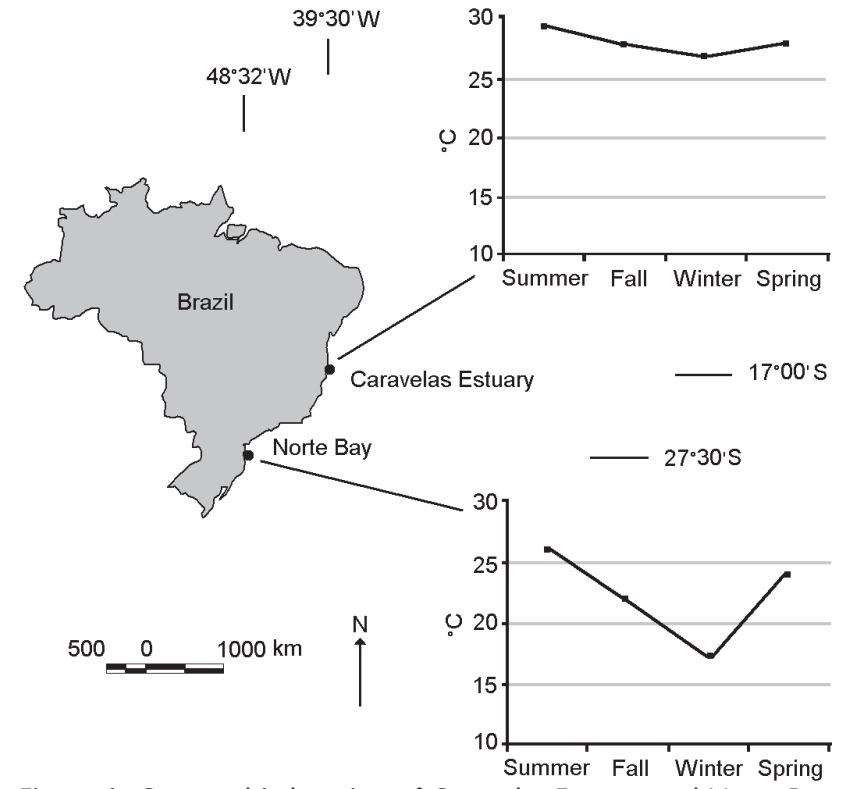

Figure 1. Geographic location of Caravelas Estuary and Norte Bay study areas on the Brazilian coast, with seasonal variation of mean temperatures $\left({ }^{\circ} \mathrm{C}\right)$. Source of temperature data: Laboratório de Cultivo de Moluscos Marinhos (Norte Bay) - data gathered in 2000 and not published; Instituto Baleia Jubarte (Caravelas) - data gathered since 2002 and not published.

\section{Data gathering and analysis}

Using the focal-group sampling (LeHNer 1996) in both study areas, data such as geographic position (GPS) and predominant activity sampling (see MANN 1999) - denoted here as predominant behavioral patterns, or simply behavior - of the groups were registered at every five-minute interval, totalling 155 hours of direct observation for Norte Bay, and 133 hours for Caravelas Estuary (Tab. I). Experienced researchers performed the observations. Although different in each area, they had the same training during preliminary observations and were always the same in the whole period of study.

The behavioral patterns considered in the present work were adapted from SHANE et al. (1986), as follows: foraging (FO) - short and asynchronic dives, abundant aerial events, movements in varying directions (except for cooperative feeding) and, many times, the presence of seabirds; the dolphins could be either in the same area, or moving in a defined direction; and travelling $(\mathrm{T})$ - moving steadily in one direction, with synchronised dives. Other behavioral patterns, such as resting and socializing, were excluded from our analyses due to small frequency of occurrence.

The geographic positions were plotted in digitized nautical charts from each region using ArcView GIS 3.2 (Environment Systems Research Institute - ESRI). As a result, maps were generated with all records of daily continuous movement tracks 
Table I. Sampling characteristics, total frequency of each behavior and mean of the index of movement intensity in both study areas between hot and cold seasons. (DO) Direct observation, (FO) foraging behavior, (T) travelling behavior, (IMI) index of movement intensity.

\begin{tabular}{|c|c|c|c|c|c|c|c|c|}
\hline & Season & Days & DO (h) & FO & FO\% & $T$ & $\mathrm{~T} \%$ & IMI \\
\hline \multirow[t]{3}{*}{ Norte Bay } & Hot & 19 & 81.1 & 877 & 90.04 & 97 & 9.96 & 2.375 \\
\hline & Cold & 17 & 70.4 & 722 & 85.44 & 123 & 14.56 & 3.229 \\
\hline & Total & 36 & 151.5 & 1599 & 87.91 & 220 & 12.09 & - \\
\hline \multirow[t]{3}{*}{ Caravelas } & Hot & 36 & 48.0 & 503 & 87.32 & 73 & 12.67 & 2.694 \\
\hline & Cold & 54 & 87.1 & 943 & 90.23 & 102 & 9.77 & 2.786 \\
\hline & Total & 90 & 135.1 & 1446 & 89.20 & 175 & 10.80 & - \\
\hline Total & All & 126 & 286.6 & 3045 & 88.52 & 395 & 11.48 & - \\
\hline
\end{tabular}

of estuarine dolphin groups for each area. Then, using the ArcView extension "Animal Movement Analyst Extension" (Hooge \& Eichenlaub 1997), the total distance travelled by the group for each day of observation was calculated. As the distance travelled by dolphin groups is a variable that may change with time, the daily mean speed of the groups was used as an index of movement intensity (IMI). Only the sequential data without sampling interruption were considered, thus avoiding distortions of the index.

Frequency variation of behavioral patterns and IMI were compared between areas and within the same area in different seasons. The overall IMI analyses were tested using the MannWhitney test, whereas the relative frequency of the behavioral patterns were analysed through the Chi-square test (5\%, SOKAL $\&$ Rohlf 1995). The seasons were grouped in hot season (Norte Bay - spring 2001/2002 and summer 2002/Caravelas - spring 2002/2003 and summer 2003) and cold season (Norte Bay fall 2002/2003 and winter 2002/Caravelas - fall 2002/2003 and winter 2002/2003).

\section{RESULTS}

The frequencies of behaviors were similar between Norte Bay and Caravelas $\left(\chi^{2}=1.298 ; \mathrm{df}=1 ; \mathrm{p}=0.254\right)$, and foraging was the most common behavior in both areas. However, in Norte Bay the frequencies of behaviors were different between cold and hot seasons $\left(\chi^{2}=8.573 ; \mathrm{df}=1 ; \mathrm{p}=0.003\right)$. Travelling frequency was higher in cold season than in hot season, while foraging frequency was higher in hot season than in cold season. Contrasting the seasonal pattern verified in Norte Bay, the frequencies of behaviors were constant throughout the year in Caravelas $\left(\chi^{2}=2.976 ; \mathrm{df}=1 ; \mathrm{p}=0.084\right.$; Tab. I and Fig. 2).

The overall index of movement intensity was similar between the two areas (Mann-Whitney: $\mathrm{U}=1692.00 ; \mathrm{Z}(\mathrm{U})=$ $0.3614 ; \mathrm{p}=0.717$; Fig. 3 ). As the results about behavioral patterns indicated, a seasonal variation on movement intensity was detected only in Norte Bay (Mann-Whitney: $U=85.00 ; \mathrm{Z}$ $(U)=2.424 ; p=0.015)$, while in Caravelas this variation was not observed (Mann-Whitney: $U=1101.00 ; \mathrm{Z}(\mathrm{U})=0.1105 ; \mathrm{p}=$ 0.911). The IMI of Norte Bay was significantly higher in cold

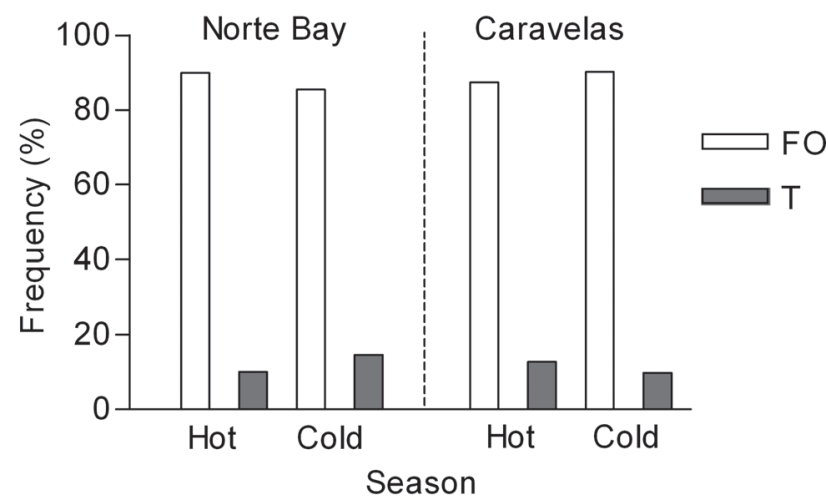

Figure 2. Relative frequency of foraging (FO) and travelling ( $\mathrm{T}$ ) in both study areas between hot and cold seasons.

seasons $($ mean $=3.23 \mathrm{~km} / \mathrm{h})$ than in the hot season $($ mean $=$ $2.37 \mathrm{~km} / \mathrm{h}$ ). This seasonal variation was not observed in Caravelas, where the index was similar between hot $($ mean $=$ 2.69) and cold seasons (mean $=2.78)$ (Tab. I and Fig. 4).

\section{DISCUSSION}

Both populations of Sotalia guianensis presented distinct seasonal patterns of movement intensity and behavioral frequencies. As it had been observed in previous studies of movement intensity (DAura-Jorge et al. 2004), behavior (DAURA-Jorge et al. 2005) and spatial use (WeDEKIN et al. 2007), our results show that the Norte Bay population has higher spatial requirements during cold seasons, moving more intensively and frequently. This pattern was not observed for Caravelas, where estuarine dolphins have the same behavior frequencies and movement intensity throughout the year.

Distinct ecological conditions between Norte Bay and Caravelas may account for the observed variations in the behavioral responses of the two populations studied. Ecological differences between two habitats are usually the result of several interacting factors, such as water temperature, transparency, salinity, tides, currents, light, depth and habitat struc- 

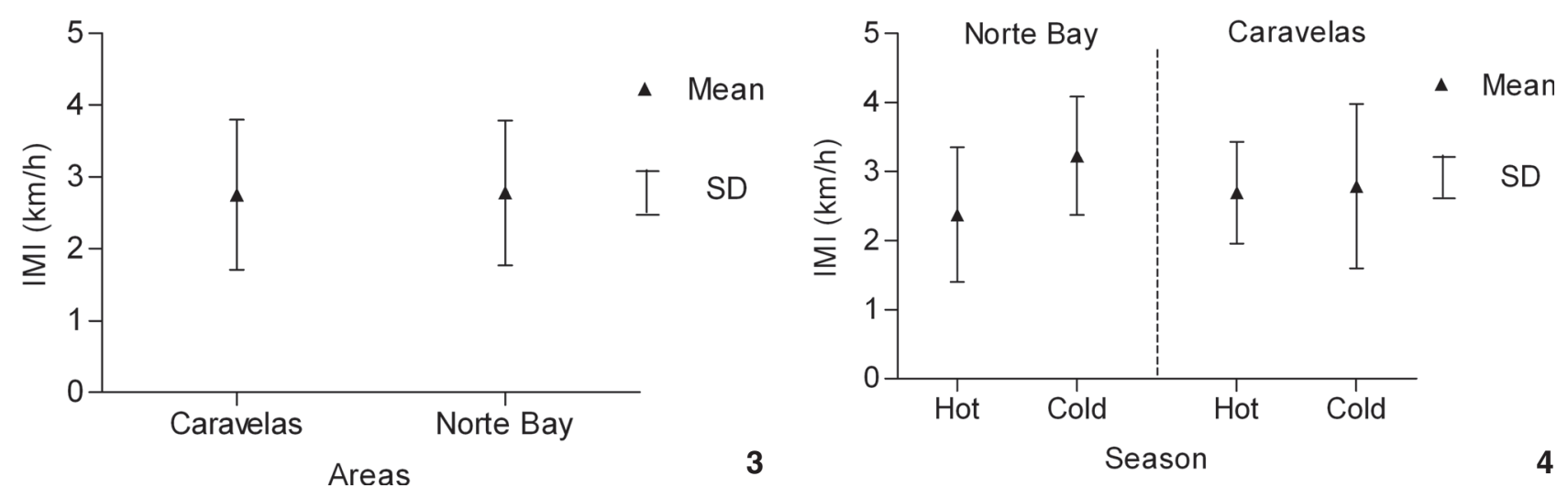

Figures 3-4. Index of movement intensity (IMI) of Sotalia guianensis for both study areas (3) and in hot and cold seasons of Norte Bay and Caravelas. (SD) standard deviation.

ture. In the absence of available data on these factors, the use of temperature as a surrogate for environment variability is quite common. Water temperature is an easily measurable parameter and an excellent indicator of changes in ecological and environmental conditions (LAEvastu \& HaYes 1981). The temperature range of an area is also correlated with latitude, increasing from lower to middle and high latitudes, tropical to sub-tropical and temperate environments (STEvens 1989). Moreover, the temperature is positively correlated with species diversity of a habitat, indicating a latitudinal gradient of species diversity, well documented for marine and terrestrial assemblages of animals (see STEvens 1989). Comparing the diversity of fish species in different estuaries along the north-south coast of the Western Atlantic, VieIRA \& Musick (1993) observed that lower latitudes (tropical estuaries) tend to have more species and more equitability among them than temperate and subtropical areas.

In Norte Bay, the annual range in the temperature may promote (through distinct processes depending on the species involved) a strong seasonality of dominant prey items of the estuarine dolphin. For example, the low temperatures occurring during the fall trigger the reproductive migration of mullet (Mugil platanus; Günter, 1880) northward along the southern Western Atlantic (VIEIRA \& SCALAbrini 1991). The presence of this important fishing resource in certain periods of the year, a potential prey item of the estuarine dolphin in Norte Bay, may influence the behavior of this species, which responds by moving more intensively and frequently in order to capture this highly mobile prey. The influence of mullets on the behavior of the estuarine dolphin has already been suggested (e.g. AraúJO et al. 2001, Flores \& BAZZALO 2004). Other fish species from the family Engraulidae (such as Cetengraulis edentulus; Cuvier, 1828 - see Daura-Jorge et al. 2004), Clupeidae and/or Scianidae, all potential prey items of the estuarine dolphin, may also play a major role in determining the seasonal patterns observed in Norte Bay. The same may not be the case of Caravelas, which is located at a lower latitude and influenced by a wider range of ecosystems, such as mangroves, coral reefs and open waters, presenting a higher diversity of fish species but without a marked dominance of one single species in certain periods (NONAKA et al. 2000).

Comparing different populations of Tursiops truncatus, WüRSIG et al. (1991) suggested that in habitats with well-defined local abundance of some prey, the behavior patterns and habitat use by dolphins also tend to be well defined. On the other hand, when the habitat shows a higher species diversity without a specific dominant prey, these behavioral patterns become diffused or non-existent. Comparatively, the tropical waters of Caravelas may be characterized as a more diverse and uniform habitat in terms of prey, while Norte Bay presents a predictable and well-defined pattern, caused by dominance of certain species in specific periods of the year.

Associations between temperature and behavior patterns of cetacean have already been observed (e.g. SHANE 1990a, BRÄGER 1993). Shane (1990a) noted that Tursiops truncatus increases the time spent in feeding activity when the temperature falls. BRÄGER (1993) registered a similar pattern with the same species, suggesting the necessity of higher energetic requirements due to the decrease of the water temperature. Another explanation suggested by the author was that the time that dolphins spend feeding increases in the fall in response to the decreasing prey abundance due to fish emigration during that season. This relation between behavioral responses of small cetaceans and the dynamic of its prey is also well documented by other authors (e.g. Wells et al. 1980, Shane et al. 1986, Selzer \& Payne 1988, Reilly 1990, Jaquet \& Whitehead 1996, Fiedler et al. 1998, AcevedoGutierrez \& PARKer 2000).

A better knowledge on the diet of the estuarine dolphin (including seasonal variations of prey ingested by different populations), the dynamics of prey abundance and distribution and, finally, the influence of the diverse physical-chemical parameters of the water in the biotic components would 
help to unravel and explain processes involving the complex associations between the physical environment, prey and predators in these coastal areas. The standardization of methodologies used in different areas would help future comparisons in dolphin studies.

\section{ACKNOWLEDGMENTS}

The Brazilian Research Bureau (Conselho Nacional de Desenvolvimento Científico e Tecnológico) funded P.C. SimõesLopes (Proc: 304698/2006-7), L.L. Wedekin and F.G. DauraJorge; M. Rossi-Santos (Projeto Boto Sotalia/Instituto Baleia Jubarte) thanks the financial support provided by Petrobrás and Aracruz Celulose, besides all the IBJ team, specially Marcia Engel and Uilson "Lixinha" Farias. We also thank Vitor Piacentini, Roberto Fusco and Karim H. Lüchmann for the review and suggestions.

\section{REFERENCES}

Acevedo-gutierrez, A. \& N. Parker. 2000. Surface behavior of bottlenose dolphins is related to spatial arrangement of prey. Marine Mammal Science 16 (2): 287-298.

Araújo, J.P.; J.Z.O. Passavante \& A.S. Souto. 2001. Behavior of the estuarine dolphin, Sotalia guianensis, at Dolphin Bay Pipa - Rio Grande do Norte - Brazil. Tropical Oceanography 29: 13-23.

Ballance, L.T. \& R.L. Pitman. 1998. Cetaceans of the Western Tropical Indian Ocean: distribution, relative abundance, and comparisons with cetacean communities of two other tropical ecosystems. Marine Mammal Science 14 (3): 429-459.

Borobia, M.; S. Siciliano; L. Lodi \& W. Hoek. 1991. Distribution of the South American dolphin Sotalia fluviatilis. Canadian Journal of Zoology 69: 1025-1039.

BRÄGER, S. 1993. Diurnal and seasonal behavior patterns of bottlenose dolphins (Tursiops truncatus). Marine Mammal Science 9 (4): 434-438.

Cremer, M.J.; F.A.S. Hardt.; A.J.T. Junior.; P.C.A. Simões-Lopes \& J.S.R. PIRES. 2004. Core area changes in Sotalia guianensis (Cetacea, Delphinidae) population in Babitonga Bay, Santa Catarina. Revista Univille 9: 130-134.

Daura-Jorge, F.G.; L.L. Wedekin \& P.C. Simões-Lopes. 2004. Variação sazonal na intensidade dos deslocamentos do boto-cinza, Sotalia guianensis (Cetacea: Delphinidae), na Baía Norte da Ilha de Santa Catarina. Biotemas 17: 203-216.

Daura-Jorge, F.G.; L.L. Wedekin;V. Q. Piacentini \& P.C. SimõesLopes. 2005. Seasonal and daily patterns of group size, cohesion and activity of the estuarine dolphin, Sotalia guianensis (P. J. van Bénéden) (Cetacea, Delphinidae), in southern Brazil. Revista Brasileira de Zoologia 22 (4): 10141021.

EKAU, W. \& B. KNOPPERS. 1999. An introduction to the pelagic system of the North-East and East Brazilian shelf. Archive of Fishery and Marine Research 47: 113-132.
Fiedler, P.C.; J. Barlow \& T. Gerrodette. 1998. Dolphin prey abundance determined from acoustic backscatter data in eastern Pacific surveys. Fishery Bulletin 96: 237-247.

FLores, P.A.C. 1999. Preliminary results of a photo-identification study of the marine tucuxi, Sotalia fluviatilis, in Southern Brazil. Marine Mammal Science 15: 840-847.

Flores, P.A.C. \& M. BAzZALo. 2004. Home range and movement patterns of the marine tucuxi dolphin, Sotaia fluviatilis, in Baía Norte, southern Brazil. Latin American Journal of Aquatic Mammals 3: 37-52.

Geise, L.; N. Gomes \& R. Cerqueira. 1999. Behavior, habitat use and population size of Sotalia fluviatilis (Gervais, 1853) in the Cananéia estuary region, São Paulo, Brazil. Brazilian Journal of Biology 59: 183-194.

Herz, R. 1991. Manguezais do Brasil. São Paulo, Universidade de São Paulo, 227p.

Hooge, P. N. \& B. Eichenlaub, 1997. Animal movement extension to ArcView (version 1.1). Anchorage, Alaska Biological Science Center, United States Geological Survey.

JAQUET, N. \& H. WhitehEAD. 1996. Scale-dependent correlation of sperm whale distribution with environmental features and productivity in South Pacific. Marine Ecology Progress Series 135: 1-9.

Krebs, J.R. \& N.B. Davies. 1993. An introduction to behavioral ecology. London, Blackwell Science, 420p.

Laevastu, T. \& M. L. Hayes. 1981. Fisheries oceanography and ecology. Farnham, Fishing News Books, 199p.

Lehner, P.N. 1996. Handbook of ethological methods. Cambridge, University Press, 672p.

ManN, J. 1999. Behavioral sampling methods for cetaceans: a review and critique. Marine Mammal Science 15: 102-122.

Monteiro-filho, E.L.A. 1995. Pesca interativa entre o golfinho Sotalia fluviatilis guianensis e a comunidade pesqueira da região de Cananéia. Boletim do Instituto de Pesca 22 (2): $15-23$.

NonAKA, R.H.; Y. MatsuUra, Y. \& K. SUZUKI. 2000. Seasonal variation in larval fish assemblages in relation to oceanographic conditions in the Abrolhos Bank region off eastern Brazil. Fishery Bulletin 98: 767-784.

OAtes, J.F. 1987. Food distribution and foraging behavior, p. 197-209. In: B.B. Smuts; D.L. Cheney; R.M. Seyfarth; R.W. Wrangham \& T.T. Struhsaker (Eds). Primate societies. Chicago, The University of Chicago Press, 578p.

ReILly, S.B. 1990. Seasonal changes in distribution and habitat differences among dolphins in the eastern tropical Pacific. Marine Ecology Progress Series 66: 1-11.

Santos, M.C. de O.; S. Rosso; S. Siciliano; A. N. Zerbini; E. Zampirolli; A. Vicente \& F. Alverenga. 2000. Behavioral observations of the marine tucuxi dolphin (Sotalia fluviatilis) in São Paulo estuarine waters, Southeastern Brazil. Aquatic Mammals 26 (3): 260-267.

Selzer, L.A. \& P.M. Payne. 1988. The distribution of white-sided (Lagenorhynchus acutus) and common dolphins (Delphinus

Revista Brasileira de Zoologia 24 (2): 265-270, junho 2007 
delphis) vs. environmental features of the continental shelf of the northeastern United States. Marine Mammal Science 4: 141-153.

Shane, S.H. 1990a. Behavior and ecology of the bottlenose dolphins at Sanibel Island, Florida, p. 245-265. In: S. LEATHERwood \& R.R. Reeves (Eds). The Bottlenose Dolphin. San Diego, Academic Press, 643p.

SHANE, S.H. 1990b. Comparison of bottlenose dolphin behavior in Texas and Florida, with a critique of methods for studying dolphin behavior, p. 541-558. In: S. LEATHERWOOD \& R.R. REEVES (Eds). The bottlenose dolphin. San Diego, Academic Press, $643 p$.

Shane, S.H.; R.S. Wells \& B. Würsig. 1986. Ecology, behavior and social organization of the bottlenose dolphin: a review. Marine Mammal Science 2: 34-63.

SIMÕEs-LoPES, P.C. 1988. Ocorrência de uma população de Sotalia fluviatilis (Gervais), 1853, (Cetacea, Delphinidae) no limite sul de sua distribuição, Santa Catarina, Brasil. Biotemas 1: 57-62.

Sokal, R.R. \& F.J. Rohlf. 1995. Biometry. New York, W.H. Freeman, 887p.

Stevens, G.C. 1989. The latitudinal gradient in geographical range: how so many species coexist in the tropics. American Naturalist 133: 240-256.

VieIra, J.P. \& C. Scalabrin. 1991. Migração reprodutiva da tainha
(Mugil platanus: Günter, 1880) no sul do Brasil. Atlântica 13: 131-141.

VieIRA, J.P. \& J.A. Musick. 1993. Latitudinal patterns in diversity of fishes in warm-temperate and tropical estuarine waters of western Atlantic. Atlântica, Rio Grande, 15: 115-113.

Wedekin, L.L.; F.G. Daura-Jorge; V.Q. Piacentini \& P.C. SimõesLOPEs. 2007. Seasonal variation on the spatial use of the estuarine dolphin, Sotalia guianensis (Cetacea, Delphinidae) in its southern limit of distribution. Brazilian Journal of Biology 67 (1): 1-8.

Wells, R.S.; A.B. Irvine \& M.D. Scott. 1980. The social ecology of inshore odontocetes, p. 263-317. In: L.M. HERMAN (Ed.). Cetacean behavior, mechanisms and functions. New York, John Wiley, 463p.

Würsig, B. \& M. Würsig. 1979. Behavior and ecology of the bottlenose dolphin, Tursiops truncatus, in the South Atlantic. Fishery Bulletin 77: 399-412.

Würsig, B. \& M. Würsig. 1980. Behavior and ecology of the dusky dolphin, Lagenorhynchus obscurus, in the South Atlantic. Fishery Bulletin 77: 871-890.

WÜrsig, B.; F. Cipriano \& M. WÜrsig. 1991. Information from radio and theodolite tracking studies, p. 79-111. In: K.A. PRYOR \& K.S. NorRIs (Eds). Dolphin societies: discoveries and puzzles. Berkeley, University of California Press, 397p.

Received in 13.III.2006; accepted in 24.IV.2007. 